\title{
FINANCIAL RATIO ANALYSIS OF SBI [2009 - 2016]
}

\author{
S. Subalakshmi ${ }^{1}$, S. Grahalakshmi ${ }^{2}$ and M. Manikandan ${ }^{3}$ \\ ${ }^{1,2}$ Department of Commerce, Standard Fireworks Rajaratnam College for Women, India \\ ${ }^{3}$ Department of Commerce, Ayya Nadar Janaki Ammal College, India
}

\begin{abstract}
SBI is the India's largest commercial bank in terms of assets, deposits and employees. SBI is the preferred banker for most of public sector corporations. It occupies a unique place in the Indian money market as it commands more than one third of India's bank resources. Public has enormous faith in State bank of India because of its dedicated services. This study aims at analyzing the Financial Ratio analysis of State Bank of India. The main objective for commercial bank is to maximize the value of profit. To do so, banks concentrate on their financial performance analysis and attempt to structure their portfolios in order to maximize their return. The most popular tool/technique for analyzing the Financial Statement of Bank is Ratio Analysis. Ratio analysis enables the management of banks to identify the causes of the changes in their advances, income, deposits, expenditure, profits and profitability over the period of time and thus helps in pinpointing the direction of action required for increasing the deposits, income, advances and reducing the expenditure and for altering the profitability prospects of the banks in future. Therefore the study was undertaken to analyze financial status of public sector bank especially to SBI (State Bank of India).
\end{abstract}

Keywords:

Commercial Bank, SBI, Public Sector Corporations, Financial Status

\section{INTRODUCTION}

Banks are life blood and the nervous system of the Indian economy. Banking plays an important role in the economic development of a country and forms the core of the money market in an advanced country. In India, the money market is characterized by the existence of both the organized and unorganized sectors. The organized sector includes Commercial banks, Co-operative banks and Regional Rural banks while the unorganized sector includes indigenous bankers and private money lenders. Among the banking institutions in the organized sector, the commercial banks are the oldest institutions having a wide network of branches, commanding utmost public confidence and having the lion's share in the total banking operations. Initially, they were established as corporate bodies with share-holdings by private individuals, but subsequently there has been a drift towards State ownership and control. Today 27 banks constitute the strong public sector in Indian commercial banking [1].

In Modern times banking is the kingpin of all business activity. It is an important instrument of mobilizing the community's resources through institutional framework. As a matter of fact, economic and industrial development of a country depends, is the main, upon how efficiently funds are managed by the banks. Hence, banking plays an important in the economic development of the country. Adequacy of capital and competency of management are the two pillars upon which the earnings of the banks depend. Sufficiency of capital instills depositor's confidence, which helps in mobilizing of deposits. Increase in deposits increases the lending business and therefore enhances the possibilities of income generation for the bank. Moreover, a bank with a sound capital base can take business opportunity more effectively and can concentrate well on dealing with problem arising from unexpected loses. The success and survival of a bank depends to a great extent upon the dedication and competence of its managers. A smart bank manager can, not only help to mobilize resources and deploy them in profitable channels, the manager can also reduce the amount of idle balances and help to earn more profits. The banks now focus on integrated balancesheet management where all the relevant factors which effect an appropriate balance sheet composition deserve consideration. Therefore various components of balance sheet are analyzed keeping in view the strengths of a bank. Analyzing Asset and Liability behaviour means managing both assets and liabilities simultaneously for the purpose of minimizing the adverse impact of interest rate movement, providing liquidity and enhancing the market value of equity. A careful designing and management of Asset and Liability behaviour is integral part of banking business particularly because over three forth of its resources originate from the depositors. However, the banks do not have free hand in the making of their behaviour on both sides (asset and liabilities). Therefore the study was undertaken to analyze financial status of public sector bank especially to SBI (State Bank of India).

The major objectives of the study are as follows:

- To study the comprehensive of growth and structure of SBI.

- To examine Assets and Liabilities Portfolio of SBI.

- To analyze the financial performance of the SBI.

- To offer suitable suggestions to strengthen the position of SBI banks.

\section{REVIEWS}

The researcher an attempt has been made to provide an overview of various aspects of this study through the review of literature. The sources referred to include various journals, books, magazines and internet sites.

Khataybeh et al. [2] determined the influence of yields or rate of return on portfolio composition and concluded that the availability of funds is more important in determining the structure of these portfolios.

Baser et al. [3] indicated that Asset-Liability Management (ALM) was a comprehensive and dynamic framework for measuring, monitoring and managing the market risk of a bank. The study attempted to evaluate the changing perspectives of the banks in identifying and facing the risks and maintaining Asset Quality so as to ensure profitability with the help of ALM techniques. 
Prathap et al. [4] indicated ALM in Indian banking system is still in a nascent stage. Against this backdrop, the objective of the research was to study and analyze the status of ALM approach in the Indian banking system. This study also indicates a strong relationship between fixed assets and net worth for all groups of banks.

Chaudhary et al. [5] stated that recently the Indian economy has witnessed the emergence of many banks in the private sector. There are several reasons behind the increasing number of commercialization of banks. The growth of such banks is not possible unless they witness some success in the context of customer satisfaction or may it be the net assets held by these banks, efficiency of their management or the networks of each bank both in private as well as the public sector bank.

Arias et al. [6] presented an econometric model to study the determinants of profitability of the top five banks of United States. The study observed that capital asset ratio had positive impact on profitability as large banks had ability to compete efficiently even if the macroeconomic factor did not support.

Ibrahim et al. [7] stated that Indian scheduled commercial banks have improved their operational performance since 2000. There is constant increase in aggregate deposits. The C-D ratio also shows an increasing trend. The investment deposit ratio and priority sector advances have also gone up.

Ravinder et al. (2011) analyzed the profitability of four major banks in India. The study revealed that State Bank of India performed better in terms of earning per share and dividend payout ratio, while Punjab National Bank performed better in terms of operating profit margin and return on equity [8].

Devamohan et al. [9], calculated the business ratios, such as interest income to average working funds, non-interest income to average working funds, operating profit to average working funds, return on assets, business per employee and profit per employee for public sector banks, private sector banks and foreign banks for the period 2004-05 to 2008-09. It was observed that the foreign banks and new generation private banks have superior business ratios. They effectively leverage technology, outsourcing and workforce professionalism which helped them to protect their bottom line.

Vyas et al. [10] used multiple regression models to compare mean capital to risk weighted assets ratio of various bank groups. They found a significant difference in the CRAR (Capital to Risk Weighted Asset Ratio) of State Bank of India group and Foreign Banks operating in India in comparison to that of nationalized banks group. There is no significant difference in the CRAR of Indian private banks and that of nationalized banks, the study observed.

Pasupathy et al. [11] stated that there were several factors that determined the operating efficiency and profitability of the bank.
The results were summarized in capsule form. Therefore, he recommended that the burden rate should be reduced by effecting cost control measures, and the spread rate be increased so that the profitability may be at a higher rate.

Sinha et al. [12] compared the performance of 40 Indian commercial banks using Window Analysis, considering deposit mobilizations as the output indicator. Among the in-samples banks, the private sector banks performed better than the public sector banks.

\section{IMPORTANCE OF THE STUDY}

The study is important as it is believed that banks with good Asset \& Liability behaviour can maximize their earnings and also satisfy their social objectives as required by the Government and the Reserve Bank of India. At present, when most of the public sector banks are reeling under the pressure of growing NPA, focus on aspects of Assets and Liability behaviour can help the banks to cut down their risk exposure as well as unnecessary spending so as to strengthen their balance sheet.

In the context of strong opposition for privatization of public sector commercial banks, this study attempts to analyse the financial performances of State Bank of India and to identify the reasons for the lag in performance of SBI and the possible corrective measures.

\section{METHODOLOGY}

In the present study, secondary data available over seven years: 2009-2016 from various sources have been analyzed. Researcher has heavily relied upon the Reserve bank of India publications, the Annual reports and balance sheets of SBI. Government publications such as publications of individual commercial banks were also collected for this study.

\section{FINANCIAL HIGHLIGHTS OF SBI DURING 2009-2016}

The Reserve bank of India identifies various items of assets and liabilities under schedules 1 to 12 . The Financial statements of banks are actually prepared in 18 schedules in accordance to special provision of third schedule of Section 29 of Banking Regulation Act, 1949. Out of these, 12 schedules are allocated to the Balance Sheet and schedules 13-16 are allocated to the Income Statement. The other schedules are related to notes of accounts, provision and contingencies or significant accounting policy changes.

Table.1. Balance Sheet of SBI from 2009-16 (In ‘000 omitted)

\begin{tabular}{|c|c|c|c|c|c|c|c|}
\hline Items & $\mathbf{2 0 0 9 - 1 0}$ & $\mathbf{2 0 1 0 - 1 1}$ & $\mathbf{2 0 1 1 - 1 2}$ & $\mathbf{2 0 1 2 - 1 3}$ & $\mathbf{2 0 1 3 - 1 4}$ & $\mathbf{2 0 1 4 - 1 5}$ & $\mathbf{2 0 1 5 - 1 6}$ \\
\hline \multicolumn{8}{|c|}{ Capital and Liabilities } \\
\hline Capital & $634,88,26$ & $634,99,90$ & $671,04,48$ & $684,03,40$ & $746,57,31$ & $746,57,31$ & $776,27,77$ \\
\hline $\begin{array}{c}\text { Reserves } \\
\text { and Surplus }\end{array}$ & $65314,31,60$ & $64351,04,42$ & $83280,16,10$ & $124348,98,77$ & $146623,96,30$ & $160640,96,97$ & $179816,08,85$ \\
\hline
\end{tabular}




\begin{tabular}{|c|c|c|c|c|c|c|c|}
\hline Deposits & $804116,22,68$ & $933932,81,30$ & $1043647,36,23$ & $1627402,61,19$ & $1838852,35,65$ & $2052960,78,88$ & $2253857,56,44$ \\
\hline Borrowings & $103011,60,11$ & $119568,95,50$ & $157991,35,95$ & $203723,19,69$ & $223759,70,95$ & $244663,46,71$ & $258214,39,05$ \\
\hline $\begin{array}{c}\text { Other } \\
\text { Liabilities }\end{array}$ & $80336,70,40$ & $105248,38,93$ & $80915,09,46$ & $172695,87,88$ & $181089,85,70$ & $235601,10,84$ & $271965,91,64$ \\
\hline Total & $1053413,73,05$ & $1223736,20,05$ & $1335519,23,07$ & $2133108,57,03$ & $2395981,60,98$ & $2700110,02,46$ & $2970897,64,19$ \\
\hline \multicolumn{8}{|c|}{ Assets } \\
\hline $\begin{array}{c}\text { Cash and } \\
\text { Balance } \\
\text { with RBI }\end{array}$ & 6129 & 943 & 0,61 & 895 & 11409 & 14428 & $160424,56,91$ \\
\hline $\begin{array}{c}\text { Balance } \\
\text { with Bank }\end{array}$ & $34892,97,64$ & $28478,64,57$ & $43087,22,63$ & $55653,69,49$ & $53065,74,09$ & $44193,50,13$ & $43734,89,64$ \\
\hline Investments & $285790,07,06$ & $295600,56,90$ & $312197,61,03$ & $519343,42,39$ & $578793,08,61$ & $673507,48,44$ & $705189,07,67$ \\
\hline Advances & $631914,15,20$ & $756719,44,80$ & $867578,89,01$ & $1392608,03,33$ & $1578276,68,60$ & $1692211,33,41$ & $1870260,89,28$ \\
\hline Fixed Assets & $4412,90,67$ & $4764,18,93$ & $5466,54,92$ & $9369,92,56$ & $10559,78,10$ & $12379,29,52$ & $15255,68,28$ \\
\hline $\begin{array}{l}\text { Other } \\
\text { Assets }\end{array}$ & $35112,75,96$ & $43777,84,65$ & $53113,01,62$ & $66559,46,15$ & $61190,71,20$ & $133530,86,29$ & $176032,52,41$ \\
\hline Total & $1053413,73,05$ & $1223736,20,05$ & $1335519,23,07$ & $2133108,57,03$ & $2395981,60,98$ & $2700110,02,46$ & $2970897,64,19$ \\
\hline
\end{tabular}

Source: Published Annual Report of SBI from 2009-16

Table.2. Profit and Loss account of SBI from 2009-16 ('000 omitted)

\begin{tabular}{|c|c|c|c|c|c|c|c|}
\hline Items & 2009-10 & 2010-11 & 2011-12 & 2012-13 & 2013-14 & 2014-15 & 2015-16 \\
\hline \multicolumn{8}{|c|}{ Income } \\
\hline Interest Earned & $70993,91,75$ & $81394,36,38$ & $106521,45,34$ & $119655,10,00$ & $136350,80,39$ & $152397,07,42$ & $163685,30,61$ \\
\hline Other Income & $14968,15,27$ & $15824,59,42$ & $14351,44,57$ & $16036,84,23$ & $18552,91,64$ & $22575,89,26$ & $28158,36,01$ \\
\hline Total I & $85962,07,02$ & $97218,95,80$ & $120872,89,91$ & $135691,94,23$ & $154903,72,03$ & $174972,96,68$ & $191843,66,62$ \\
\hline \multicolumn{8}{|c|}{ Expenditure } \\
\hline Interest Expended & $47322,47,80$ & $48867,95,61$ & $63230,36,87$ & $75325,79,65$ & $87068,63,25$ & $97381,82,36$ & $106803,49,21$ \\
\hline Operating Expenses & $20318,68,00$ & $23015,43,26$ & $26068,99,21$ & $29284,42,23$ & $35725,85,13$ & $38677,64,14$ & $41782,36,65$ \\
\hline Provisions for contingencies & $9154,85,92$ & $17071,05,03$ & $19866,24,97$ & $16976,73,86$ & $21218,06,48$ & $25811,92,98$ & $33307,15,39$ \\
\hline Total II & $76796,01,72$ & $88954,43,90$ & $109165,61,05$ & $121586,95,74$ & $144012,54,86$ & $161871,39,48$ & $181893,01,25$ \\
\hline \multicolumn{8}{|c|}{ Net Profit } \\
\hline I-II & $9166,05,30$ & $8264,51,90$ & $11707,28,86$ & $14104,98,49$ & $10891,17,17$ & $13101,57,20$ & $9950,65,37$ \\
\hline Profit b/f & 33,93 & 33,93 & 33,93 & 33,93 & 33,93 & 32,48 & 32,48 \\
\hline Total & $9166,39,23$ & $8264,85,83$ & $11713,33,94$ & $14105,32,42$ & $10891,51,10$ & $13101,89,68$ & $9950,97,85$ \\
\hline
\end{tabular}

Source: Published Annual Report of SBI from 2009-16

\section{RATIO ANALYSIS}

The most popular tool/technique for analyzing the Financial Statement of Bank is Ratio Analysis. Ratio analysis enables the management of banks to identify the causes of the changes in their advances, income, deposits, expenditure, profits and profitability over the period of time and thus helps in pinpointing the direction of action required for increasing the deposits, income, advances and reducing the expenditure and for altering the profitability prospects of the banks in future.

To analyses the performance of the SBI Banks, the researcher has identified 16 ratios namely:
- Credit Deposit Ratio

- Deposit to Total Assets Ratio

- Return on Equity Ratio

- Interest Expenses to Interest Earned Ratio

- Profit Margin Ratio

- Equity Multiplier Ratio

- Net Interest Margin Ratio

- NPA to Advance Ratio 


\subsection{CREDIT DEPOSIT RATIO}

Credit Deposit Ratio is a commonly used statistic for assessing a bank's liquidity by dividing the banks total loans by its total deposits. The formula used to calculate the credit deposit ratio is,

Credit Deposit Ratio $=$ Credit $/$ Deposits

The ratio of credit to deposit of SBI during the study period is shown in the following Table.3.

Table.3. Credit Deposit Ratio of SBI ('000 omitted)

\begin{tabular}{|c|c|c|c|}
\hline Year & Credit & Deposit & $\begin{array}{c}\text { Credit } \\
\text { Deposit Ratio }\end{array}$ \\
\hline $2009-10$ & $631914,15,20$ & $804116,22,68$ & 0.79 \\
\hline $2010-11$ & $756719,44,80$ & $933932,81,30$ & 0.81 \\
\hline $2011-12$ & $867578,89,01$ & $1043647,36,23$ & 0.83 \\
\hline $2012-13$ & $1392608,03,33$ & $1627402,61,19$ & 0.86 \\
\hline $2013-14$ & $1578276,68,60$ & $1838852,35,65$ & 0.86 \\
\hline $2014-15$ & $1692211,33,41$ & $2052960,78,88$ & 0.82 \\
\hline $2015-16$ & $1870260,89,28$ & $2253857,56,44$ & 0.83 \\
\hline \multicolumn{5}{|c|}{ Average $=0.83$} \\
\hline \multicolumn{5}{|c|}{ Maximum $=0.86$} \\
\hline \multicolumn{5}{|c|}{ Minimum $=0.79$} \\
\hline
\end{tabular}

Computed Secondary Data

It is inferred from the Table.3, the Credit Deposit Ratio in the year $2009-10$ is $0.79,2010-11$ is $0.8,2011-12$ is $0.83,2012-13$ is $0.86,2013-14$ is $0.86,2014-15$ is 0.82 and $2015-16$ is 0.83 . The average Credit Deposit ratio of SBI over the study period was registered as 0.83 . The minimum ratio was registered as 0.79 in the year 2009-10 and the maximum ratio was registered as 0.86 in the year 2012-13 and 2013-14.

It is concluded that, the Average Credit Deposit ratio of SBI is $83 \%$ and it indicates that out of every 100 Deposited, Rs. 83 being lent and hence it is clear that the SBI may not have enough liquidity to cover any unforeseen fund requirements.

\subsection{DEPOSIT TO TOTAL ASSETS RATIO}

The deposit to total assets ratio is an indicator of financial leverage. It describes the percentage of total assets that were financed by creditors, liabilities and debt. The deposits to total assets ratio is calculated by dividing total deposits by its total assets. The formula to calculate the deposit to total assets ratio is

Deposit to Total Assets Ratio = Deposit/Total Assets

The ratio Deposit to Total Assets of SBI during the study period is shown in the following Table.4.

Table.4. Deposit to Total Assets Ratio of SBI ('000 omitted)

\begin{tabular}{|c|c|c|c|}
\hline Year & Deposit & Total Assets & $\begin{array}{c}\text { Deposit to Total } \\
\text { Asset Ratio }\end{array}$ \\
\hline $2009-10$ & $804116,22,68$ & $1053413,73,05$ & 0.76 \\
\hline $2010-11$ & $933932,81,30$ & $1223736,20,05$ & 0.76 \\
\hline $2011-12$ & $1043647,36,23$ & $1335519,23,07$ & 0.78 \\
\hline
\end{tabular}

\begin{tabular}{|l|l|l|l|}
\hline $2012-13$ & $1627402,61,19$ & $2133108,57,03$ & 0.76 \\
\hline $2013-14$ & $1838852,35,65$ & $2395981,60,98$ & 0.77 \\
\hline $2014-15$ & $2052960,78,88$ & $2700110,02,46$ & 0.76 \\
\hline $2015-16$ & $2253857,56,44$ & $2970897,64,19$ & 0.76 \\
\hline \multicolumn{4}{|c|}{ Average $=0.77$} \\
\hline \multicolumn{4}{|c|}{ Maximum $=0.78$} \\
\hline
\end{tabular}

Computed Secondary Data

It is revealed from the Table.4, that the average Deposit to total assets ratio of SBI during the study period was 0.77 . The maximum Deposit to Total Assets Ratio has registered was 0.78 during the year 2011-12 and the minimum Deposit to total assets ratio registered was 0.76 in the years 2009-10, 2010-11, 2012-13, 2014-15 and 2015-16.

As this ratio establishes the extent of the bank's Assets being funded by Deposits. It is clear that around $76 \%$ of Total Assets is being funded by Deposits.

\subsection{EQUITY MULTIPLIER RATIO}

This ratio measures the extent to which assets of the financial institutions are funded with equity relative to debt. Equity Multiplier measures the value of assets funded per equity capital. The higher this ratio, the more leverage or debt the bank is using to fund its assets. The formula to calculate the Equity Multiplier Ratio is

Equity Multiplier Ratio = Total Assets/Total Equity Capital

The Ratio Total Assets to total equity capital of SBI during the study is shown in the following Table.5.

Table.5. Equity Multiplier Ratio of SBI ('000 omitted)

\begin{tabular}{|c|c|c|c|}
\hline Year & Total Assets & $\begin{array}{c}\text { Total Equity } \\
\text { Capital }\end{array}$ & $\begin{array}{c}\text { Equity } \\
\text { Multiplier Ratio }\end{array}$ \\
\hline $2009-10$ & $1053413,73,05$ & $634,88,26$ & 1659.22 \\
\hline $2010-11$ & $1223736,20,05$ & $634,99,90$ & 1927.15 \\
\hline $2011-12$ & $1335519,23,07$ & $671,04,48$ & 1900.21 \\
\hline $2012-13$ & $2133108,57,03$ & $684,03,40$ & 3118.42 \\
\hline $2013-14$ & $2395981,60,98$ & $746,57,31$ & 3209.31 \\
\hline $2014-15$ & $2700110,02,46$ & $746,57,31$ & 3616.67 \\
\hline $2015-16$ & $2970897,64,19$ & $776,27,77$ & 3827.11 \\
\hline \multicolumn{4}{|c|}{ Average $=2743.17$} \\
\hline \multicolumn{4}{|c|}{ Maximum $=3827.11$} \\
\hline \multicolumn{4}{|c|}{ Minimum =1659.22 } \\
\hline
\end{tabular}

Computed Secondary Data

The Table.5 reveals clearly that the average Equity Multiplier ratio of SBI during the study period was registered as 2743.17. The maximum of Multiplier Ratio was registered as 3827.11 in the year 2015-16 and the minimum Multiplier Ratio was registered as 1659.22 in the year 2009-10.

Higher the ratio indicates that more Assets were funding by Debt than by Equity. In other words, investors funded fewer assets 
than by creditors. This involves more risk for the investors because the SBI is highly levered with Debt.

\subsection{RETURN ON EQUITY RATIO}

It measures the amount of net income after taxes earned for Equity Capital contributed by the bank's stock holders. The formula to calculate the return on Equity ratio is

Return on Equity Ratio = Net income/Total Equity Capital

The ratio Net Income to total equity capital of SBI during the study Period is shown in the following Table.6.

Table.6. Return on Equity Ratio of SBI ('000 omitted)

\begin{tabular}{|c|c|c|c|}
\hline Year & Net Income & Equity Capital & $\begin{array}{c}\text { Return on } \\
\text { Equity Capital }\end{array}$ \\
\hline $2009-10$ & $9166,39,23$ & $634,88,26$ & 14.44 \\
\hline $2010-11$ & $8264,85,83$ & $634,99,90$ & 13.02 \\
\hline $2011-12$ & $15866,02,25$ & $671,04,48$ & 23.64 \\
\hline $2012-13$ & $18808,97,28$ & $684,03,40$ & 27.50 \\
\hline $2013-14$ & $10891,51,10$ & $746,57,31$ & 14.59 \\
\hline $2014-15$ & $13101,89,68$ & $746,57,31$ & 17.55 \\
\hline $2015-16$ & $9950,97,85$ & $776,27,77$ & 12.82 \\
\hline \multicolumn{4}{|c|}{ Average $=20.16$} \\
\hline \multicolumn{4}{|c|}{ Maximum $=27.50$} \\
\hline \multicolumn{5}{|c|}{ Minimum $=12.82$} \\
\hline
\end{tabular}

Computed Secondary Data

The Table. 6 shows that the average returns on equity ratio of SBI during the study period have registered as 20.16. The maximum ratio was registered as 27.50 in the year 2012-13 and the minimum average returns on equity ratio was registered as 12.82 in the year 2015-16 during the study period.

The Average Return on Equity ratio is 20.16 and this indicates how well the SBI is making effective use of the shareholder's capital. In other words Higher the Return on Equity will be better.

\subsection{INTEREST EXPENSES TO OPERATING INCOME RATIO}

Interest expenses constitute the major part of Total expenses incurred by any bank. Interest is paid on the amount deposited by customers on various schemes like Fixed Deposit Schemes and Savings bank account. The formula to calculate the interest expenses ratio is,

$$
\text { Interest Expenses Ratio }=\frac{\text { Interest Expenses }}{\text { Total Operating Income }}
$$

The ratio Interest expenses to total operating income of SBI during the study period is shown in the following Table.7.

It is apparent from the Table.7 that the average Interest expenses ratio of SBI during the study period was 0.63 . The maximum interest expenses ratio was 0.67 in the year 2009-10 and the minimum interest expenses ratio was registered as 0.59 2011-12 during the study period.
It can be concluded that, the SBI always maintains around 67 percentage of excess of interest earned over interest expended on around $35 \%$.

Table.7. Interest Expenses Ratio of SBI ('000 omitted)

\begin{tabular}{|c|c|c|c|}
\hline Year & $\begin{array}{c}\text { Interest } \\
\text { Expenses }\end{array}$ & $\begin{array}{c}\text { Operating } \\
\text { Income }\end{array}$ & $\begin{array}{c}\text { Interest } \\
\text { Expenses Ratio }\end{array}$ \\
\hline $2009-10$ & $47322,47,80$ & $70993,91,75$ & 0.67 \\
\hline $2010-11$ & $48867,95,61$ & $81394,36,38$ & 0.60 \\
\hline $2011-12$ & $63230,36,87$ & $106521,45,34$ & 0.59 \\
\hline $2012-13$ & $106817,91,29$ & $167976,13,88$ & 0.64 \\
\hline $2013-14$ & $121479,04,34$ & $189062,44,04$ & 0.64 \\
\hline $2014-15$ & $97381,82,36$ & $152397,07,42$ & 0.64 \\
\hline $2015-16$ & $106803,49,21$ & $163685,30,61$ & 0.65 \\
\hline \multicolumn{5}{|c|}{ Average $=0.63$} \\
\hline \multicolumn{5}{|c|}{ Maximum $=0.67$} \\
Computed Secondary Data
\end{tabular}

\subsection{PROFIT MARGIN RATIO}

Profit Margin measures bank's ability to control expenses and thus its ability to produce net income from its operating income (or revenue). These ratios measure the proportion of total operating income that goes to pay the particular expense item. The formula to calculate the Profit Margin Ratio is,

Profit Margin Ratio $=$ Net Income/Total Operating Income

The ratio Net Income to Total Operating income of SBI during the study period is shown in the following Table.8.

Table.8. Profit Margin Ratio of SBI ('000 omitted)

\begin{tabular}{|c|c|c|c|}
\hline Year & Net Income & $\begin{array}{c}\text { Total } \\
\text { Operating } \\
\text { Income }\end{array}$ & $\begin{array}{c}\text { Profit } \\
\text { Margin } \\
\text { Ratio }\end{array}$ \\
\hline $2009-10$ & $9166,39,23$ & $70993,91,75$ & 0.13 \\
\hline $2010-11$ & $8264,85,83$ & $81394,36,38$ & 0.10 \\
\hline $2011-12$ & $15866,02,25$ & $106521,45,34$ & 0.15 \\
\hline $2012-13$ & $18808,97,28$ & $167976,13,88$ & 0.11 \\
\hline $2013-14$ & $10891,51,10$ & $189062,44,04$ & 0.06 \\
\hline $2014-15$ & $13101,89,68$ & $152397,07,42$ & 0.09 \\
\hline $2015-16$ & $9950,97,85$ & $163685,30,61$ & 0.06 \\
\hline \multicolumn{4}{|c|}{ Average $=0.11$} \\
\hline \multicolumn{4}{|c|}{ Maximum $=0.15$} \\
\hline
\end{tabular}

Computed Secondary Data

The Table. 8 highlights that the average profit margin ratio of SBI during the study period was registered as 0.11 . The maximum average profit margin ratio was registered as 0.15 in the year 2011-12 and the minimum average profit margin ratio was registered as 0.06 in the year 2015-16. 
The Average Profit Margin ratio is $11 \%$ and this low profit margin indicates the expenses are too high and need to cut expenses.

\subsection{NET INTEREST MARGIN RATIO}

The most important ratio when it comes to banks is the Net Interest margin. Net Interest Margin is the difference between the interest income generated and the amount of interest paid out to their lenders deposit divided by total assets. The Net Interest Margin is calculated by using the formula,

Net Interest Margin $=\frac{(\text { Interest Earned-Interest Expended })}{\text { Total Assets }}$

The Net Interest Margin of SBI during the study period is shown in the following Table.9.

Table.9. Net Interest Margin ratio of SBI ('000 omitted)

\begin{tabular}{|c|c|c|c|c|}
\hline Year & $\begin{array}{c}\text { Interest } \\
\text { Earned }\end{array}$ & $\begin{array}{c}\text { Interest } \\
\text { Expended }\end{array}$ & Total Assets & $\begin{array}{c}\text { Net } \\
\text { Interest } \\
\text { Margin }\end{array}$ \\
\hline $2009-10$ & $70993,91,75$ & $47322,47,80$ & $1053413,73,05$ & 0.02 \\
\hline $2010-11$ & $81394,36,38$ & $48867,95,61$ & $1223736,20,05$ & 0.03 \\
\hline $2011-12$ & $106521,45,34$ & $63230,36,87$ & $1335519,23,07$ & 0.03 \\
\hline $2012-13$ & $167976,13,88$ & $106817,91,29$ & $2133108,57,03$ & 0.03 \\
\hline $2013-14$ & $189062,44,04$ & $121479,04,34$ & $2395981,60,98$ & 0.03 \\
\hline $2014-15$ & $152397,07,42$ & $97381,82,36$ & $2700110,02,46$ & 0.02 \\
\hline $2015-16$ & $163685,30,61$ & $106803,49,21$ & $2970897,64,19$ & 0.02 \\
\hline \multicolumn{5}{|c|}{ Mverage $=0.025$} \\
\hline \multicolumn{5}{|c|}{ Minimum =0.02 0.03} \\
\hline \multicolumn{5}{|c|}{$|c|$} \\
\hline
\end{tabular}

Computed Secondary Data

It is apparent from the above Table 9, that the average Net Interest Margin of SBI during the Study period was 0.025 . The maximum Net Interest margin of SBI is 0.03 in the years 2010-11, 2011-12, 2012-13 and 2013-14. The minimum Net interest Margin of SBI is 0.02 in the years 2009-10, 2014-15 and 2015-16.

The Average Net Interest Margin ratio of SBI is $2.5 \%$. The positive of the Net Margin indicates the SBI investment strategy costs more than it makes and was able to make optimal decision, as interest expenses were lower than the amount of returns produced by investments.

\subsection{NPA TO ADVANCE RATIO}

NPA is defined as a credit facility in respect of which the interest and/ or installment of principal has remained past due for a specified period of time. In simple terms, asset is tagged as nonperforming when it ceases to generate income for the lender the net NPA to loans (advance) ratio is used as a measure of the overall quality of the bank's loan. An NPA are those assets for which interest is overdue for more than 90 days (or 3 months).

NPA Ratio $=($ Net Non-Performing Assets $) /$ Loans

The Ratio Non- performing assets to loans given of SBI during the study period is shown in the following Table.10.
Table.10. NPA to Advance Ratio of SBI (in crores)

\begin{tabular}{|c|c|c|c|}
\hline Year & Net NPA & Advance & $\begin{array}{c}\text { NPA to Advance Ratio } \\
(\%)\end{array}$ \\
\hline $2009-10$ & 10870.17 & 631914.15 & 1.72 \\
\hline $2010-11$ & $12,346.90$ & 756719.44 & 1.63 \\
\hline $2011-12$ & 15818.85 & 867578.89 & 1.82 \\
\hline $2012-13$ & $21,956.48$ & 1392608.03 & 1.58 \\
\hline $2013-14$ & $31,096.07$ & 1578276.69 & 1.97 \\
\hline $2014-15$ & $27,590.58$ & 1692211.33 & 1.63 \\
\hline $2015-16$ & $55,807.02$ & 1870260.89 & 2.98 \\
\hline \multicolumn{5}{|c|}{ Average $=2.31$} \\
\hline \multicolumn{5}{|c|}{ Maximum $=2.98$} \\
\hline \multicolumn{5}{|c|}{ Minimum = 1.63 } \\
\hline
\end{tabular}

Computed Secondary Data

It is observed from the above Table.10, the average NPA to advance ratio of SBI during the study period is $2.31 \%$. The Maximum NPA to Advance ratio was registered at $2.98 \%$ and the minimum NPA to Advance ratio was registered at 1.63 in the year 2015-16 and 2010-11 respectively.

It is concluded that the NPA to Advance ratio has a fluctuating trend and starts increasing after 2015. So the SBI bank has strictly followed the RBI guidelines by making provisions against NPAs. While situation was in control till 2014-15, the ratio increased to around 3 following the effective steps taken by RBI Governor Raghuram Rajan to clean up the balance sheets of banks by eliminating the hidden NPAs.

The present study has been undertaken for critical evaluation of only the leading Public sector bank in India, State Bank of India. The study period is of seven years from 2009-10 to 201516. In this study, the financial ratio analysis of SBI has been evaluated. The researcher pinpoints the emerging conclusion of the study based on analysis carried out and puts forward suggestions on the basis of the findings of the research work.

\section{FINDINGS}

- The research work provides the key findings according to the data analysis.

- It is concluded that, the Average Credit Deposit ratio of SBI is $83 \%$ and it indicates that out of every 100 Deposited, 83 being lent.

- It is clear from the Deposit to Total Assets ratio that around $76 \%$ of Total Assets is being funded by Deposits.

- The maximum Multiplier Ratio was registered at 3827.11 in the year 2015-16 and the minimum Multiplier Ratio was registered at 1659.22 in the year 2009-10.

- It is understand that the Average Return on Equity ratio is 20.16 during the study period.

- It can be concluded from the Interest Expenses ratio that the SBI always maintains the percentage of excess of interest earned over interest expended at around 35\%.

- It is clear that, the Average of Profit Margin ratio comparing the Interest earned and Net income is $11 \%$ during the study period. 
- The maximum of Net Interest margin ratio of SBI is 0.03 in the years 2010-11, 2011-12, 2012-13 and 2013-14 and the minimum Net interest Margin ratio of SBI is 0.02 in the years 2009-10, 2014-15 and 2015-16.

- The Maximum of NPA to Advance ratio was registered at $2.98 \%$ and the minimum of NPA to Advance ratio was registered at 1.63 in the year 2015-16 and 2010-11 respectively.

\section{SUGGESTIONS}

On the basis of the analysis and interpretations of the collected data, the researcher has identified some suggestions for consideration. On the basis of the study the following suggestions are given to the State Bank of India to improve their performance.

- In contrast, large banks generally lack sufficient deposits to fund their main business dealing with large companies, governments, other financial institutions, and wealthy individuals. Most borrow the funds they need from other major lenders in the form of short term liabilities which must be continually rolled over. This is known as liability management, a much riskier method than asset management. The SBI should maintain enough liquidity to cover any unforeseen fund requirements because its Credit Deposit ratio is $83 \%$ which means that out of every Rs. 100 deposited Rs.83 being lent. So there is a need to maintain sufficient liquidity.

- The Average Equity Multiplier Ratio is higher in SBI, this indicates that more Assets are funded by Debt than the Equity, involves more risky for the investors and SBI is highly levered with Debts. So the SBI should concentrate on their Equity Fund by attracting large investors to invest in their equity shares.

- The Average Profit Margin Ratio is $11 \%$. This is very low to the SBI and indicates the expenses are higher. So the SBI need to prepare efficient budget to cut off the expenses. If the expenses are high, it will create adverse impression in the minds of the shareholders, so the SBI must concentrate on it.

- The Maximum of NPA to Advance ratio was registered at $2.98 \%$ and the minimum of NPA to Advance ratio was registered at 1.63 in the year 2015-16 and 2010-11 respectively. The NPA of SBI are in increasing trend which shows in SBI bank there are more chances to convert debtors in NPA to bad debts in the near future too.

- Interest Expended to Interest Earned ratio of SBI is less satisfactory. It is suggested that the SBI Bank may take some steps to increase the interest earning capacity of the bank, by inviting more deposits from public.

- The suggestions offered would enable the SBI to take necessary steps to improve the performance of the SBI.

\section{CONCLUSION}

The present research work dealt with the performance of SBI with reference to Ratio analysis and Percentage analysis. There is a sufficient progress in the SBI and the overall performance of the Bank is good. The performance of SBI bank has been analyzed in detail in terms of deposit mobilization, loans and advances, investment position, non-performing assets, earnings and profitability efficiency. According to the analysis, the SBI is maintaining the required standards and running profitability. SBI have more profitability because it enters into the industry as well as commercial market also and regularly it improving the service quality level. In this highly competitive global environment it is imperative for the SBI bank to show outstanding performance in various parameters.

\section{REFERENCES}

[1] J.D. Agarwal, "Finance India", Available at: http://www.india_financing.com, Accessed on 2016.

[2] Alaaeddin Al-Tarawneh and Mohmmad Khataybeh, "Portfolio Behaviour of Commercial Banks: The Expected Utility Approach: Evidence from Jordan", International Journal of Economics and Financial Issues, Vol. 5, No, 2, pp. 62-68, 2015.

[3] Narayan Baser, "Asset and Liability Management of Scheduled Commercial Banks", International Journals of Marketing and Technology, Vol. 2, No. 4, pp. 20-44, 2014.

[4] Suman Chakrabotry and Subhalaxmi Mohapatra, "An Empirical Study of Asset Liability Management by Indian Banks", SSRN, pp. 1-11, 2009.

[5] Garima Chaudhary, "Performance Comparison of Private Sector Banks with the Public Sector Banks in India with Reference to Assets and Liabilities", International Journal of Emerging Research in Management and Technology, Vol. 3, No. 2, pp. 5-12, 2012.

[6] J.W. Scott and J.C. Arias, "Banking Profitability Determinants", Business Intelligence Journal, Vol. 4, No. 2, pp. 209-230, 2011.

[7] Ibrahim M. Syed, "Operational Performance of Indian Scheduled Commercial Banks-An Analysis", International Journal of Business and Management, Vol. 6, No. 5, pp. 1216, 2011.

[8] K.V.N. Prasad and G. Ravinder, "Performance Evaluation of Banks: A Comparative Study on SBI, PNB, ICICI \& HDFC", Advances in Management, Vol. 4, No. 2, pp. 43-53, 2011.

[9] Alamelu and Devamohan, "Efficiency of Commercial Banks in India”, IUP Publication, 2010.

[10] Manmeet Singh and R.K. Vyas, "Capital Adequacy and Scheduled Commercial Banks in India”, Bauddhik, Vol. 1, No. 1, pp. 18-21, 2009.

[11] Rajamohan and Pasupathy, "Performance Evaluation of Tamil Nadu Industrial Co-operative Bank Ltd.)-An Application of Structural and Growth Analysis", Indian Cooperative Review, Vol. 37, No. 2, pp. 11-15, 2009.

[12] Ram Pratap Sinha and Biswajit Chatterjee, "Bank Ownership and Deposit Mobilization: A Non-Parametric Approach", Prajnan-Journal of Social and Management Sciences, Vol. 37, No. 3, pp. 159-180, 2009. 